\title{
PENERAPAN MODEL PEMBELAJARAN KOOPERATIF TIPE ROTATING TRIO EXCHANGE UNTUK MENINGKATKAN HASIL BELAJAR MATEMATIKA KELAS VIII DI SMP NEGERI 3 KOTA BENGKULU
}

\author{
Ayu Tri Utami ${ }^{1}$, Rusdi ${ }^{2}$, Ringki Agustinsa ${ }^{3}$ \\ 1,2,3 Program Studi Pendidikan Matematika Jurusan Pendidikan MIPA \\ Fakultas Keguruan dan Ilmu Pendidikan Universitas Bengkulu \\ email : ${ }^{1}$ ayuutami0801@gmail.com, ${ }^{2}$ rusdipendmat12@gmail.com, ${ }^{3}$ ringki@unib.ac.id
}

\begin{abstract}
Abstrak
Penelitian ini bertujuan untuk mengetahui peningkatan hasil belajar matematika peserta didik Kelas VIII.5 di SMP Negeri 3 Kota Bengkulu melalui penerapan model pembelajaran kooperatif tipe Rotating Trio Exchange. Jenis penelitian yang dilaksanakan adalah Penelitian Tindakan Kelas dengan teknik pengumpulan data melalui tes hasil belajar. Subjek dalam penelitian in adalah 36 peserta didik Kelas VIII.5 SMP Negeri 3 Kota Bengkulu tahun pelajaran 2017/2018 yang terdiri dari 16 peserta didik laki-laki dan 20 peserta didik perempuan. Hasil penelitian ini menunjukkan bahwa penerapan model pembelajaran kooperatif tipe Rotating Trio Exchange dapat meningkatkan hasil belajar matematika. Peningkatan hasil belajar peserta didik dapat dilihat dari nilai rata-rata kelas pada tes akhir siklus I, II, dan III masing-masing sebesar 66,91; 73,73; dan 81,2 dengan persentase ketuntasan belajar klasikal pada siklus I, II, dan III berturut-turut yaitu 55,56\%; 72,22\%; dan 83,33\%.
\end{abstract}

Kata kunci : Hasil Belajar, Model Pembelajaran Kooperatif Tipe Rotating Trio Exchange.

\begin{abstract}
The purpose of this research is to know the improvement of students learning result at class of VIII.5 SMP Negeri 3 Bengkulu City through implement of cooperative learning model type of Rotating Trio Exchange. The Research's type is Classroom Action Research with technique of data collectin is using learning result test. The subjects of this research are 36 students of VIII.5 at SMP Negeri 3 Bengkulu City in academic year 2017/2018 that are consist of 16 male students and 20 female students. The result of this research shows that application of cooperative learning model type of Rotating Trio Exchange can improve learning result in mathematics. The improvement of learning result can be seen from average value in first cycle, second, and third cycle that are 66,91; 73,73; and 81,2 with persentage of classical completeness on first, second, and third cycle that are 55,56\%; 72,22\%; and $83,33 \%$ respectevely.
\end{abstract}

Keywords : Learning Activity, Learning Result, Cooperative Learning Model Type of Rotating Trio Exchange

\section{PENDAHULUAN}

Salah satu mata pelajaran yang memegang peranan penting dalam pendidikan adalah matematika. Hal ini ditunjukkan dengan diberikan mata pelajaran matematika pada semua jenjang pendidikan mulai dari tingkat Sekolah Dasar hingga Perguruan Tinggi. Cockroft (Abdurrahman, 2003:253) menyebutkan bahwa matematika perlu diajarkan kepada peserta didik karena (1) digunakan dalam segala segi kehidupan dan semua bidang studi; (2) sarana komunikasi yang kuat, singkat, dan jelas; (3) dapat digunakan untuk menyajikan informasi dalam berbagai cara; (4) meningkatkan kemampuan berpikir logis, ketelitian, dan kesadaran keruangan; dan (5) memberikan kepuasan terhadap usaha memecahkan masalah yang menantang. 
Hasil observasi yang dilakukan selama kegiatan magang III dari bulan Agustus sampai dengan September 2017 di SMP Negeri 3 Kota Bengkulu diketahui bahwa peserta didik belum terlibat secara aktif dalam kegiatan pembelajaran. Ketika guru memberikan tugas, terdapat peserta didik yang belum mampu mengerjakan tugas tersebut secara mandiri. Masalah lainnya adalah peserta didik belum berani mengajukan ataupun menjawab pertanyaan yang diberikan oleh guru. Hanya peserta didik tertentu saja yang mau menjawab pertanyaan dan mengerjakan soal di papan tulis. Akibatnya, pembelajaran di kelas menjadi membosankan dan motivasi belajar yang dimiliki peserta didik semakin berkurang dengan adanya pembelajaran yang kurang bervariasi tersebut. Hal itu semua berdampak pada perolehan hasil belajar matematika yang belum optimal.

Kondisi di atas didukung oleh fakta bahwa ketercapaian ketuntasan belajar peserta didik kelas VIII SMP Negeri 3 Kota Bengkulu pada Ulangan Akhir Semester (UAS) ganjil untuk tahun pelajaran 2017/2018 yang memiliki nilai rata-rata berada di bawah kriteria ketuntasan minimal, yaitu 75. Oleh karena itu, kegiatan pembelajaran di SMP Negeri 3 Kota Bengkulu, perlu mendapatkan perhatian dan upaya peningkatkan sehingga mendapatkan kualitas yang lebih baik, diantaranya dengan menerapkan model - model pembelajaran yang tepat dan sesuai dengan materi pelajaran yang dipilih.

Salah satu model pembelajaran yang sesuai untuk mengatasi masalah di atas adalah model pembelajaran kooperatif. Hal ini dikarenakan guru lebih mudah mengelompokkan peserta didik kedalam kelompok-kelompok kecil dan meminta mereka saling membantu dalam belajar serta menyelesaikan soal. Hal ini sesuai dengan pendapat Darmadi (2012:5) yang menyatakan bahwa kelompok kecil memberikan manfaat sebagai berikut :

1. Mengembangkan kemampuan berpikir dan berkomunikasi

2. Meningkatkan disiplin
3. Meningkatkan motivasi belajar

4. Mengembangkan sikap saling membantu

5. Meningkatkan pemahaman

Model pembelajaran kooperatif memiliki banyak tipe salah satunya Rotating Trio Exchange. Menurut Karim (2014:273), model pembelajaran kooperatif tipe Rotating Trio Exchange merupakan model pembelajaran yang dapat melibatkan peserta didik dalam mengulang materi agar peserta didik terlatih dalam menemukan, menguasai konsep dan pembelajaran yang berpusat pada peserta didik.

Model pembelajaran kooperatif tipe Rotating Trio Exchange memberikan kesempatan kepada peserta didik untuk berdiskusi dengan teman sekelasnya dengan cara merotasi anggota kelompok setiap kali soal baru diberikan sehingga terbentuk kelompok yang baru. Peserta didik berdiskusi dengan teman yang berbeda-beda setiap kali soal diberikan.

Menurut Harmin dan Toth (2012:132) bahwa tujuan utama bertukar teman dalam kelompok adalah memberikan pengalaman berbagi pikiran kepada peserta didik dengan sebanyak mungkin orang dengan cara yang mudah dan efisien. Dengan demikian, peserta didik akan mendapatkan berbagai pendapat dalam menyelesaikan suatu masalah.

Menurut Isjoni (2016:59) model pembelajaran kooperatif tipe Rotating Trio Exchange dilaksanakan dengan cara sebagai berikut :

(1) Berikan pada setiap trio pertanyaan yang sama untuk didiskusikan;

(2) Setelah selesai berilah nomor untuk setiap anggota trio tersebut. Contohnya nomor 0,1 , dan 2;

(3) Kemudian perintahkan nomor 1 berpindah searah jarum jam dan nomor 2 sebaliknya, berlawanan jarum jam;

(4) Sedangkan nomor 0 tetap di tempat. Ini akan mengakibatkan trio baru; dan 
(5) Berikan kepada setiap trio baru tersebut pertanyaan-pertanyaan baru untuk didiskusikan, tambahkan sedikit tingkat kesulitan.

Adapun langkah-langkah penerapan model pembelajaran kooperatif tipe Rotating Trio Exchange menurut Silberman (2016:103) dijabarkan sebagai berikut:

(1) Menyusun beragam pertanyaan yang dapat membantu peserta didik memulai diskusi mengenai materi pelajaran.

(2) Membagi peserta didik menjadi kelompok tiga orang (trio). Aturlah kelompok trio tersebut di dalam ruang kelas agar masing - masing bisa melihat dengan jelas trio yang ada di sisi kanan dan kirinya.

(3) Memberikan pertanyaan pembuka untuk setiap trio (pertanyaan yang sama untuk masing-masing trio) agar dapat dibahas secara bersama. Anjurkan tiap peserta didik dalam kelompok untuk menjawab pertanyaan.

(4) Setelah diskusi berjalan dalam waktu yang cukup, guru meminta masingmasing kelompok untuk menentukan nomor 0,1 , atau 2 kepada setiap anggotanya. Peserta didik nomor 1 berpindah ke kelompok trio satu searah jarum jam. Peserta didik nomor 2 berpindah ke kelompok trio dua searah jarum jam, sedangkan peserta didik nomor 0 tetap di tempat karena ia merupakan anggota tetap dari kelompok trio.

(5) Memulai pertukaran pendapat baru dengan memberikan pertanyaan yang baru.

(6) Guru dapat merotasi trio-trio sebanyak pertanyaan yang dimiliki dan sesuai dengan waktu yang tersedia.

(7) Untuk variasi, setiap pertanyaan selesai didiskusikan, segeralah meminta jawaban dari seluruh kelompok sebelum merotasi peserta didik ke kelompok trio baru

Pelaksanaan model pembelajaran kooperatif tipe Rotating Trio Exchange yang diterapkan pada penelitan ini adalah model Rotating Trio Exchange yang dikemukakan oleh Isjoni. Adapun langkah-langkah penerapannya sebagai berikut:

1. Guru memberikan suatu contoh yang dapat diamati ataupun pertanyaan kepada peserta didik.

2. Guru memberikan kesempatan kepada peserta didik untuk bertanya dan kemudian menjawabnya bersama-sama

3. Guru membagi peserta didik menjadi beberapa kelompok yang masingmasing beranggotakan tiga peserta didik yang selanjutnya disebut trio.

4. Setiap anggota diberi nomor 0,1 , atau 2. Dengan ketentuan bahwa peserta didik yang memiliki nomor 0 adalah peserta didik dengan tingkat pengetahuan yang tinggi, peserta didik dengan nomor 1 memiliki tingkat pengetahuan yang sedang, dan peserta didik dengan nomor 2 merupakan mereka yang memiliki tingkat pengetahuan yang rendah.

5. Guru menjelaskan prosedur diskusi yang akan dilaksanakan. Setiap kali soal selesai didiskusikan, maka peserta didik dengan nomor 1 berpindah ke kelompok yang berada searah jarum jam. Peserta didik dengan nomor 2 berpindah ke kelompok yang berlawanan arah jarum jam dan peserta didik dengan nomor 0 tetap di tempat. 


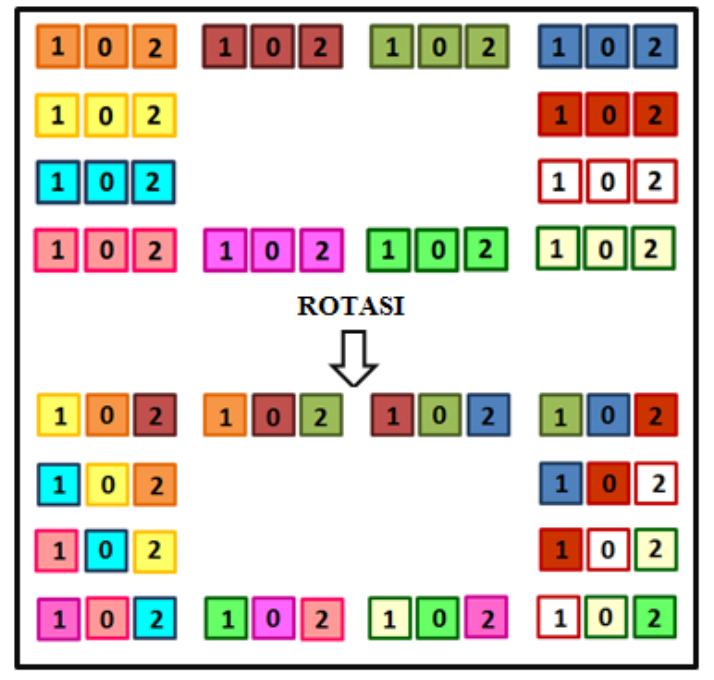

Gambar 1. Proses Perputaran (Rotating) Trio

6. Setiap trio diberikan lembar soal untuk didiskusikan selama waktu yang telah ditentukan.

7. Setelah masa waktu diskusi berakhir, guru meminta peserta didik berotasi sesuai dengan instruksi yang telah disampaikan pada awal diskusi.

8. Setiap rotasi dilakukan, maka diberikan lembar soal baru dengan tingkat kesulitan yang berbeda untuk didiskusikan oleh trio baru.

9. Perputaran trio dilakukan berkali-kali sebanyak lembar soal dan waktu yang tersedia.

10. Jika di kelas terdapat peserta didik yang tidak hadir sehingga jumlah peserta didik tidak berkelipatan tiga, maka dapat membuat variasi kelompok yang terdiri dari 4 orang

Kelebihan dari model pembelajaran kooperatif tipe Rotating Trio Exchange menurut Dipayana (2014:8-9) sebagai berikut (1) struktur yang jelas memungkinkan peserta didik untuk berbagi dengan pasangan dalam kelompoknya; (2) peserta didik mempunyai kesempatan untuk mengolah informasi yang diperoleh; dan (3) tidak menimbulka kebosanan dalam kegiatan pembelajaran.

Kelemahan yang dimiliki model pembelajaran kooperatif tipe Rotating Trio
Exchange sebagai berikut (1) Dalam setiap pembelajaran yang menggunakan model pembelajaran kooperatif tipe Rotating Trio Exchange, guru harus mempersiapkan pembelajaran dengan sungguh-sungguh; (2) Saat diskusi berlangsung, terkadang didominasi oleh seseorang dalam setiap kelompok; (3) Lebih baik diterapkan pada jumlah peserta didik berkelipatan tiga, namun tidak menutup kemungkinan diterapkan pada jumlah peserta didik yang tidak berkelipatan tiga; dan (4) Memerlukan waktu yang banyak dalam pelaksanaannya, karena setiap kelompok harus dirotasikan sehingga selalu membentuk kelompok baru.

Hasil belajar juga memiliki peranan penting dalam pembelajaran. Hasil belajar menjadi tolak ukur keberhasilan peserta didik dalam mengikuti kegiatan pembelajaran. Menurut Rusman (2017:129), hasil belajar adalah sejumlah pengalaman yang diperoleh peserta didik yang mencakup ranah kognitif, afektif, dan psikomotor. Dalam penelitian ini, hasil belajar yang digunakan adalah hasil belajar pada ranah kognitif.

Ranah kognitif oleh Anderson direvisi dengan mengubah penamaan yang semulanya menggunakan kata benda menjadi kata kerja. Ranah kognitif yang direvisi oleh Anderson, tidak lagi memuat sintesis dan menambahkan kata kerja menciptakan sebagai tingkat tertinggi dalam sistem berpikir yang harus terintegrasi dalam tujuan pembelajaran. Berikut ini ranah kognitif yang telah direvisi oleh Anderson (2010:99-133) :

(1) Mengingat adalah mengambil pengetahuan yang relevan dari memori jangka panjang. Termasuk didalamnya mengenali dan mengingat kembali.

(2) Memahami adalah mengkonstruksi makna dari materi pembelajaran, termasuk apa yang diucapkan, ditulis, dan digambar guru. Kegiatan yang mencakup ranah ini adalah menafsirkan, mencontohkan, mengklasifikasi, merangkum, menyimpulkan, membandingkan, dan menjelaskan. 
(3) Mengaplikasikan atau menerapkan adalah menggunakan suatu prosedur untuk mengerjakan soal latihan atau menyelesaikan masalah yang berhubungan erat dengan pengetahuan prosedural. Termasuk didalamnya adalah mengeksekusi dan mengimplementasikan.

(4) Menganalisis meliputi menguraikan suatu permasalahan atau obyek menjadi bagianbagian kecil dan menentukan bagaimana hubungan antar bagian tersebut dan antara setiap bagian dan struktur keseluruhannya, meliputi membedakan, mengorganisasikan , dan mengatribusikan.

(5) Mengevaluasi adalah membuat suatu pertimbangan atau penilaian berdasarkan kriteria dan standar yang ada. Termasuk didalamnya adalah memeriksa dan mengkritik.

(6) Mencipta yaitu memadukan bagianbagian untuk membentuk sesuatu yang baru dan koheren atau untuk membuat suatu produk yang orisinal. Termasuk didalamnya adalah merumuskan, merencanakan, dan memproduksi

Pencapaian hasil belajar peserta didik dapat diketahui dengan melaksanakan tes hasil belajar pada setiap akhir siklus. Hal tersebut dilakukan untuk mengetahui sejauh mana peserta didik dapat mengikuti pembelajaran kooperatif tipe Rotating Trio Exchange yang peneliti terapkan. Hasil belajar ini juga dapat dijadikan sebagai bahan evaluasi bagi peneliti pada tahap refleksi disetiap siklusnya.

Berdasarkan penjelasan di atas, dapat dikatakan bahwa model pembelajaran kooperatif tipe Rotating Trio Exchange merupakan salah satu cara yang tepat untuk diterapkan pada pembelajaran matematika agar peserta didik dapat aktif berdiskusi dan bekerjasama dalam menyelesaikan setiap soal yang diberikan bersama anggota kelompok yang berbeda-beda setiap kali soal baru diberikan.

\section{METODE}

Jenis penelitian yang dilakukan adalah Penelitian Tindakan Kelas (Classroom Action Reserach). Menurut Trianto (2011:16), Penelitian Tindakan Kelas adalah penelitian kualitatif yang dilakukan oleh guru sendiri ketika mendapatkan permasalahan dalam pembelajaran dan mencarikan solusinya dalam upaya memperbaiki kualitas pembelajaran.

Penelitian ini dilaksanakan di Kelas VIII.5 SMP Negeri 3 Kota Bengkulu pada semester genap tahun pelajaran 2017/2018, tepatnya mulai dari tanggal 22 Maret sampai dengan 12 Mei 2018. Adapun Subjek Penelitian Tindakan Kelas ini berjumlah 36 peserta didik, 16 lakilaki dan 20 perempuan.

Penelitian ini dilaksanakan dengan menerapkan model pembelajaran kooperatif tipe Rotating Trio Exchange selama 3 siklus. Setiap siklus terdiri dari (1) perencanaan (planning); (2) pelaksanaan tindakan (action); (3) observasi (observation); dan (4) refleksi (reflection).

Teknik pengumpulan data yang digunakan meliputi lembar observasi, tes hasil belajar, dan dokumentasi. Lembar observasi digunakan untuk mengamati aktivitas peserta didik selama proses pembelajaran terdiri dari 10 pernyataan mengenai aktivitas peserta didik yang diamati. Tes hasil belajar berupa pemberian soal essai yang diberikan pada setiap akhir siklus.

Data dianalisis secara kualitatif dan kuantitatif. Data kualitatif berupa data hasil observasi dan data kuantitatif berupa data tes hasil belajar peserta didik setelah mengikuti kegiatan pembelajaran kooperatif tipe Rotating Trio Exchange. Hasil belajar peserta didik tersebut kemudian dihitung rata-ratanya sebagai berikut.

$$
X=\frac{\sum x}{\sum N}
$$

(Aqib, 2014:40)

Keterangan :

$\sum x=$ jumlah nilai

$\sum N=$ jumlah peserta didik 
Peserta didik dikatakan tuntas secara individu jika mendapatkan nilai minimal 75 , sedangkan secara klasikal minimal $80 \%$ peserta didik Kelas VIII.5 mendapatkan nilai lebih dari sama dengan 75. Persentase ketuntasan belajar klasikal dihitung dengan menggunakan perhitungan berikut ini

$$
p=\frac{\sum \text { siswa yang tuntas belajar }}{\sum \text { siswa }} \times 100 \%
$$

Penerapan model pembelajaran kooperatif tipe Rotating Trio Exchange pada mata pelajaran matematika dapat dikatakan berhasil apabila ada peningkatan hasil belajar matematika peserta didik dengan rata-rata nilai tes akhir siklus peserta didik $\geq 75$ dengan persentase ketuntasan belajar klasikal minimal $80 \%$.

\section{HASIL DAN PEMBAHASAN Hasil Penelitian}

Sebelum melaksanakan pembelajaran, peneliti mempersiapkan rencana pelaksanaan pembelajaran, lembar soal diskusi, soal tes akhir siklus I, media pembelajaran yang dibutuhkan, dan membagi peserta didik ke dalam kelompok-kelompok yang berbeda berdasarkan nilai ulangan akhir semeseter ganjil tahun pelajaran 2017/2018. Pelaksanaan pembelajaran dengan menerapkan model pembelajaran kooperatif tipe Rotating Trio Exchange dilaksanakan dalam tiga siklus.

Siklus I dilaksanakan selama 4 pertemuan mulai dari tanggal 22 Maret sampai dengan 31 Maret 2018. Pada akhir pertemuan keempat, peserta didik diberikan tes akhir siklus I. Pada siklus I, peserta didik mengalami kesulitan dalam proses perputaran (rotating) trio yang dilakukan. Peneliti berusaha memberikan instruksi dengan menggunakan kata-kata yang lebih sederhana agar proses pembelajaran dapat berlangsung dengan lancar.

Hasil tes akhir siklus I kemudian dianalisis dan diperolehlah informasi sebagai berikut.
Tabel 1. Hasil Tes Akhir Siklus I

\begin{tabular}{cc}
\hline Deskripsi & Hasil Analisis \\
\hline \hline Jumlah Peserta Didik & 36 \\
\hline Jumlah Peserta Didik Tuntas & 20 \\
\hline $\begin{array}{c}\text { Jumlah Peserta Didik Belum } \\
\text { Tuntas }\end{array}$ & 16 \\
\hline Rata-rata Kelas & 66,91 \\
\hline Persentase Ketuntasan Klasikal & $55,56 \%$ \\
\hline Kesimpulan & Belum berhasil \\
\hline
\end{tabular}

Tabel di atas menunjukkan bahwa pembelajaran dengan menerapkan model pembelajaran kooperatif tipe Rotating Trio Exchange pada siklus I diperoleh nilai rata-rata peserta didik sebesar 66,91 dengan persentase ketuntasan belajar klasikal sebesar 55,56\%. Hal tersebut berarti lebih dari setengah peserta didik Kelas VIII.5 mendapatkan nilai $\geq 75$. Berdasarkan tes akhir siklus I, diketahui bahwa peserta didik kesulitan dalam menyelesaikan soal penerapan. Hal ini dikarenakan peserta didik membaca soal secara terburu-buru dan tidak teliti sehingga informasi yang diterima peserta didik belum lengkap. Akibatnya, peserta didik tidak bisa memahami soal dengan baik dan ada juga peserta didik yang salah menafsirkan soal yang diberikan.

Nilai rata-rata dan persentase ketuntasan yang diperoleh pada siklus I tersebut belum mencapai indikator keberhasilan penelitian sehinggga sehingga pembelajaran dilanjutkan ke siklus II dengan melakukan beberapa perbaikan.

Siklus II dilaksanakan mulai dari tanggal 3 April sampai dengan 17 April 2017. Pada siklus II ini, peneliti memberikan waktu bagi peserta didik untuk membaca soal secara keseluruhan. Untuk meningkatkan keterlibatan peserta didik dalam membaca soal maka peneliti meminta salah satu peserta didik untuk membacakannya secara lantang sedangkan peserta didik yang lainnya menyimak dan menemukan informasi-informasi yang ada pada soal tersebut. Tujuan dari kegiatan ini adalah membiasakan peserta didik untuk membaca soal secara menyeluruh dan teliti agar dapat menyelesaikan soal-soal yang diberikan 
peneliti dengan baik, terutama soal yang berupa penerapan.

Peneliti memberikan 5 soal kepada peserta didik yang memuat indikator-indikator pencapaian kompetensi pembelajaran pada siklus II sebagai tes akhir siklus II. Hasil pelaksanaan tes akhir siklus II dapat dilihat pada tabel berikut ini.

Tabel 2. Hasil Tes Akhir Siklus II

\begin{tabular}{cc}
\hline Deskripsi & Hasil Analisis \\
\hline \hline Jumlah Peserta Didik & 36 \\
\hline Jumlah Peserta Didik Tuntas & 26 \\
\hline $\begin{array}{c}\text { Jumlah Peserta Didik Belum } \\
\text { Tuntas }\end{array}$ & 10 \\
\hline Rata-rata Kelas & 73,73 \\
\hline Persentase Ketuntasan Klasikal & $72,22 \%$ \\
\hline Kesimpulan & Belum berhasil \\
\hline
\end{tabular}

Berdasarkan Tabel 2, diketahui bahwa hasil belajar peserta didik pada siklus II mengalami peningkatan. Hal tersebut ditunjukkan dengan adanya peningkatan hasil tes akhir siklus II dibandingkan dengan siklus I.

Pada siklus II, nilai rata-rata peserta didik mencapai 73,73 dengan persentase ketuntasan klasikal sebesar 72,22\%. Pada siklus ini, masih terdapat peserta didik yang belum teliti dalam membaca gambar yang ada pada soal. Hal tersebut dapat saja terjadi karena peserta didik belum teliti dan terburu-buru dalam mengerjakannya.

Perolehan nilai rata-rata dan persentase ketuntasan klasikal pada siklus II belum memenuhi indikator keberhasilan penelitian. Dengan demikian, pembelajaran kooperatif tipe Rotating Trio Exchange dilanjutkan ke siklus III dengan dilakukannya beberapa perbaikan.

Pelaksanaan siklus III dimulai dari tanggal 3 Mei sampai dengan 12 Mei 2018. Tes akhir siklus III dilaksanakan pada akhir pertemuan keempat dengan jumlah soal yang diberikan sebanyak 6 soal dalam waktu 80 menit. Berikut ini data yang diperoleh dari tes akhir siklus III.
Tabel 3. Hasil Tes Akhir Siklus III

\begin{tabular}{cc}
\hline Deskripsi & Hasil Analisis \\
\hline \hline Jumlah Peserta Didik & 36 \\
\hline Jumlah Peserta Didik Tuntas & 30 \\
\hline $\begin{array}{c}\text { Jumlah Peserta Didik Belum } \\
\text { Tuntas }\end{array}$ & 6 \\
\hline Rata-rata Kelas & 81,20 \\
\hline Persentase Ketuntasan Klasikal & $83,33 \%$ \\
\hline Kesimpulan & Berhasil \\
\hline
\end{tabular}

Tabel 3 menunjukkan peningkatan hasil belajar peserta didik dengan nilai rata-rata sebesar 81,20 dan persentase ketuntasan klasikal mencapai $83,33 \%$. Jawaban yang diberikan peserta didik semakin sistematis dan teliti. Dengan perolehan nilai tersebut maka indikator keberhasilan dalam penelitian ini telah tercapai sehingga pembelajaran dengan menerapkan model pembelajaran kooperatif tipe Rotating Trio Exchange dapat dihentikan.

\section{Pembahasan}

Penelitian tindakan kelas dengan menerapkan model pembelajaran kooperatif tipe Rotating Trio Exchange di Kelas VIII.5 SMP Negeri 3 Kota Bengkulu yang dilaksanakan selama 3 siklus dapat meningkatkan hasil belajar peserta didik. Hal tersebut dibuktikan berdasarkan hasil tes akhir siklus yang dilaksanakan pada setiap siklusnya. Tujuan diberikannya tes hasil belajar kepada peserta didik adalah mengetahui perubahan yang terjadi pada peserta didik ketika diterapkan model pembelajaran kooperatif tipe Rotating Trio Exchange, terutama perubahan hasil belajar pada ranah kognitif. Berikut ini perubahan hasil belajar peserta didik Kelas VIII.5 pada setiap siklusnya.

Tabel 4. Perbandingan Hasil Tes Akhir Siklus I, II, dan III

\begin{tabular}{cccc}
\hline \multirow{2}{*}{ Deskripsi } & \multicolumn{3}{c}{ Siklus } \\
\cline { 2 - 4 } & I & II & III \\
\hline \hline $\begin{array}{c}\text { Jumlah Peserta } \\
\text { Didik }\end{array}$ & 36 & 36 & 36 \\
\hline $\begin{array}{c}\text { Jumlah Peserta } \\
\text { Didik Tuntas }\end{array}$ & 20 & 26 & 30 \\
\hline Rata-rata Kelas & 66,91 & 73,73 & 81,20 \\
\hline
\end{tabular}




\begin{tabular}{cccc}
\hline $\begin{array}{c}\text { Persentase } \\
\text { Ketuntasan Klasikal }\end{array}$ & $55,56 \%$ & $72,22 \%$ & $83,33 \%$ \\
\hline
\end{tabular}

Tabel 4 menunjukkan bahwa hasil belajar peserta didik Kelas VIII.5 SMP Negeri 3 Kota Bengkulu mengalami peningkatan pada setiap siklusnya. Peningkatan tersebut dapat terlihat pada nilai rata-rata peserta didik dan persentase ketuntasan belajar klasikal.

Nilai rata-rata peserta didik Kelas VIII.5 pada setiap siklusnya menunjukkan peningkatan. Rata-rata nilai tes akhir siklus I adalah 66,91. Nilai tersebut mengalami peningkatan pada siklus II dan III masingmasing sebesar 6,82 dan 7,47. Berikut ini grafik peningkatan nilai rata-rata peserta didik Kelas VIII.5 pada setiap siklusnya.

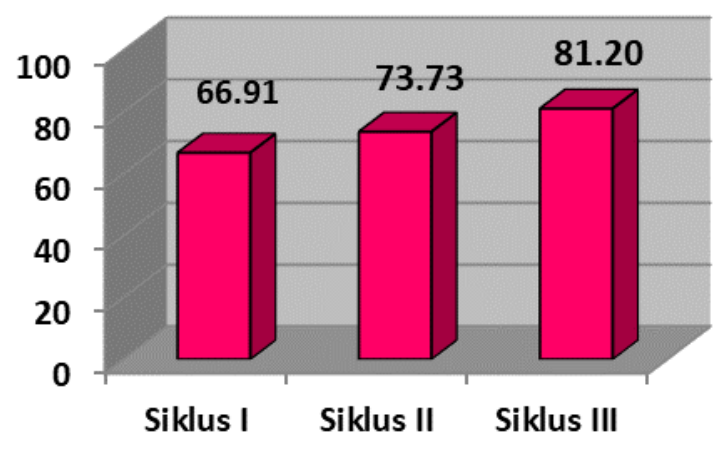

\section{Gambar 2. Nilai Rata-rata Peserta Didik Setiap Siklusnya}

Hasil pelaksanaan siklus I diketahui bahwa lebih dari setengah jumlah peserta didik atau sebanya $55,56 \%$ peserta didik Kelas VIII.5 tuntas belajar dan mendapatkan nilai lebih dari nilai KKM yang ditentukan pihak sekolah, yaitu 75. Hasil tersebut mengalami peningkatan pada siklus II dan siklus III masing-masing sebesar $18,17 \%$ dan $9,6 \%$. Berikut ini grafik peningkatan persentase ketuntasan belajar klasikal.

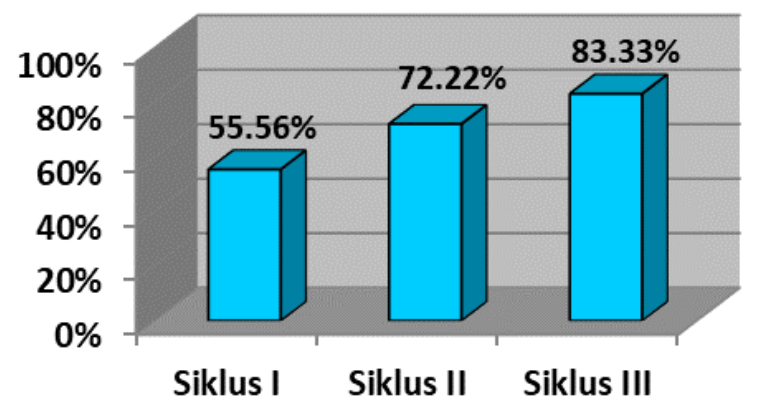

\section{Gambar 3. Persentase Ketuntasan Klasikal Setiap Siklus}

Peningkatan tidak hanya ditunjukkan dari nilai rata-rata peserta didik dan ketuntasan belajar secara klasikal. Namun, peningkatan tersebut juga dapat dilihat dari nilai masingmasing peserta didik pada setiap siklusnya. Peningkatan nilai tes akhir pada setiap siklusnya terjadi pada 21 peserta didik atau sebesar 58,33\% dari jumlah seluruh peserta didik Kelas VIII.5 dan sisanya mengalami peningkatan dan penurunan nilai pada beberapa siklusnya. Selain itu, persentase peserta didik yang belum pernah mencapai nilai lebih dari 75 selama tiga siklus pembelajaran hanya terjadi pada 3 peserta didik atau hanya $8,33 \%$ dari jumlah seluruh peserta didik.

Model pembelajaran kooperatif tipe Rotating Trio Exchange dapat meningkatkan hasil belajar peserta didik melalui kegiatan berdiskusi dengan anggota kelompok yang berbeda-beda setiap kali soal baru diberikan. Anggota kelompok dalam Rotating Trio Exchange dapat dijadikan sebagai teman belajar dan mendapatkan berbagai pendapat mengenai penyelesaian suatu soal dari temanteman yang berbeda.

Jumlah anggota kelompok yang terdiri dari tiga peserta didik dapat memaksimalkan keterlibatan peserta didik dalam kegiatan diskusi. peserta didik tidak memiliki kesempatan untuk melakukan aktivitas yang tidak sesuai dengan pembelajaran seperti mengobrol ketika pelaksanaan diskusi, karena ketika kedua teman kelompoknya aktif dalam berdiskusi, peserta didi yang pada awalnya malas akhirnya termotivasi dan ikut berdiskusi 
menyelesaikan soal yang diberikan peneliti. Hal tersebut didukung oleh pendapat Harmin dan Toth (2012:134) yang menyatakan bahwa kelompok yang terdiri dari tiga peserta didik lebih baik dibandingkan dengan kelompok yang terdiri dari empat peserta didik karena tujuan membentuk kelompok adalah memaksimalkan keterlibatan peserta didik. Dengan demikian, peserta didik dapat terlibat aktif dalam proses diskusi dan peserta didik dapat saling membantu dalam belajar.

Selain itu, perputaran (rotating) trio memberikan kesempatan kepada peserta didik untuk berdiskusi dengan banyak teman. Dengan demikian, peserta didik mendapatkan pengetahuan dari beberapa sumber yang berbeda. Dengan adanya pertukaran kelompok ini dapat meningkatkan komunikasi antar peserta didik sehingga hubungan antara peserta didik yang satu dengan yang lainnya menjadi lebih akrab.

Adanya aktivitas fisik pada proses perputaran (rotating) trio dapat meningkatkan semangat peserta didik sehingga peserta didik dapat lebih fokus dalam menerima informasi. Hal tersebut sesuai dengan pendapat Nurhayati (2013:4) yang menyatakan bahwa pergerakan anggota tubuh menambah rasa rileks dan kenyamanan pada peserta didik dalam belajar, sehingga perputaran (rotating) trio yang dilakukan tersebut memberikan efek menyenangkan bagi peserta didik tanpa ada waktu yang tersia-siakan untuk melakukan hal lainnya yang disebabkan peserta didik yang merasa bosan selama pembelajaran.

Selama kegiatan diskusi berlangsung. Peneliti menemukan bahwa peserta didik belum terbiasa membaca soal dalam bentuk penerapan. Peserta didik cenderung membaca terburu-buru dan belum membacanya secara menyeluruh. Akibatnya, peserta didik kesulitan dalam mengerjakan soal penerapan yang peneliti berikan. Untuk mengatasi masalah ini, peneliti berusaha membiasakan peserta didik untuk membaca soal secara keseluruhan dengan teliti. Untuk mengatasi hal tersebut, peneliti memberikan waktu kepada peserta didik untuk membaca soal penerapan terlebih dahulu sebelum memulai diskusi. Peneliti meminta salah satu peserta didik membacakan soal dengan lantang, sedangkan peserta didik yang lainnya menyimak dan menemukan informasiinformasi yang terdapat pada soal dengan dibantu oleh pertanyaan-pertanyaan yang peneliti berikan.

Cara yang peneliti lakukan tersebut bertujuan untuk (1) Meningkatkan keterlibatan peserta didik dalam mengerjakan soal; (2) Membiasakan peserta didik untuk membaca soal terlebih dahulu secara keseluruhan ; dan (3) Meningkatkan kefokusan peserta didik dikarenakan mereka tidak hanya diminta untuk membaca dan mendengarkan, akan tetapi mereka juga harus mampu menemukan informasi-informasi yang ada pada soal untuk menjawab pertanyaan yang diberikan peneliti.

\section{PENUTUP}

\section{Kesimpulan}

Berdasarkan hasil penelitian mengenai peningkatan aktivitas dan hasil belajar peserta didik melalui penerapan model pembelajaran kooperatif tipe Rotating Trio Exchange di kelas VIII.5 SMP Negeri 3 Kota Bengkulu dapat diambil kesimpulan sebagai berikut:

(1) Model pembelajaran kooperatif tipe Rotating Trio Exchange dengan tindakan sebagai berikut :
a. Membentuk kelompok yang terdiri dari 3 orang yang memiliki tingkat pengetahuan yang berbeda;
b. memberikan lembar yang berisi soal;
c. Membimbing peserta didik yang mengalami kesulitan pada kegiatan diskusi;
d. Melakukan perputaran (rotating) trio sehingga peserta didik dapat berdiskusi dengan teman yang berbeda-beda; dan
Membiasakan peserta didik
membaca soal terlebih dahulu
dengan teliti dapat meningkatkan 
hasil belajar peserta didik Kelas VIII.5 SMP Negeri 3 Kota Bengkulu.

(2) Peningkatan hasil belajar peserta didik ditunjukkan dari nilai rata-rata peserta didik pada siklus I sebesar 66,91; siklus II sebesar 73,73; dan 81,20 pada siklus III. Peningkatan juga terjadi pada persentase ketuntasan belajar klasikal pada siklus I, II, dan III masing-masing sebesar 55,56\%; 72,22\%; dan 83,33\%.

\section{Saran}

Berdasarkan penelitian yang telah dilakukan, maka peneliti menyarankan sebagai berikut:

1. Penerapan model pembelajaran kooperatif tipe Rotating Trio Exchange dapat dijadikan alternatif variasi dalam proses pembelajaran untuk meningkatkan aktivitas dan hasil belajar peserta didik pada pembelajaran matematika.

2. Kesulitan terletak pada peserta didik yang berkemampuan rendah sehingga diperlukan pengelolaan yang lebih baik dalam pelaksanaan kegiatan pembelajaran

3. Peneliti berikutnya yang akan meneliti penelitian serupa sebaiknya lebih memperhatikan soal yang diberikan kepada peserta didik. Tingkat kesukaran soal harus dipertimbangkan dengan baik sehingga soal yang diberikan tersebut dapat mengajak peserta didik untuk berdiskusi.

\section{DAFTAR PUSTAKA}

Abdurrahman, Mulyono. 1999. Pendidikan Bagi Anak Berkesulitan Belajar. Jakarta: PT Rineka Cipta.

Anderson, Lorin W, dan Krathwohl, David R. 2010. Kerangka Landasan Untuk Pembelajaran, Pengajaran, dan Asesmen. Yogyakarta: Pustaka Pelajar.

Aqib, dkk. 2014. Penelitian Tindakan Kelas. Jakarta: PT Bumi Aksara.
Dipayana, I Md Dyatma. 2014. "Pengaruh Strategi Pembelajaran Rotating Trio Exchange (RTE) Terhadap Hasil Belajar Matematika". Mimbar PGSD Universitas Pendidikan Ganesha, Vol. 2, No. 1, hal 8-9. Harmin, Merril dan Toth, Melanie. 2012. Pembelajaran yang Menginspirasi. Jakarta: Indeks.

Isjoni. 2016. Cooperative Learning Efektifitas Pembelajaran Kelompok. Bandung: ALFABETA.

Karim, Saifudin Nor Haris Saputera. 2014. "Pengaruh Model Pembelajaran Kooperatif Tipe Rotating Trio Exchange (RTE) Terhadap Kemampuan Komunikasi Matematis Pada Peserta didik SMP”. EDUMAT Jurnal Pendidikan Matematika, Vol. 2, No. 3, hal 271-278.

Lestari, Karunia Eka dan Yudhanegara, Mokhammad Ridwan. 2015. Penelitian Pendidikan Matematika. Bandung : PT Refika Aditama.

Nurhayati, Wahyu, Elva Yasmi Amran, dan Erviyenni. 2013. Penerapan Model Pembelajaran Kooperatif Rotating Trio Exchange (RTE) Sebagai Upaya Peningkatan Prestasi Belajar Siswa Pada Pokok Bahasan Reaksi Reduksi Oksidasi di Kelas X SMA Negeri 2 Pekanbaru. Riau: Program Sarjana Universitas Riau.

Rusman. 2017. Belajar dan Pembelajaran Berorientasi Standar Proses Pendidikan. Jakarta: Kencana.

Silberman, Melvin. 2016. Active Learning 101 Strategi Pembelajaran. Bandung : Penerbit Nuansa.

Trianto. 2011. Panduan Lengkap Penelitian Tindakan Kelas (Classroom Action Research) Teori dan Praktik. Jakarta : Prestasi Pustakaraya. 